\title{
Macroeconomic performance of the Israeli economy in the 21st millennium ${ }^{1}$
}

\author{
Yochanan Shachmurove', Ben-Zion Zilberfarb ${ }^{3}$
}

\begin{abstract}
The Israeli economy in the first two decades of the 21st century is an example of an economic transformation that may serve as a role model for addressing many challenges to economic growth. Data from this period have shown significant developments in economic growth over this relatively short period of time and indicate that these advances are attributable to policies targeting inflation, labor force participation and education. While challenges remain-including economic inequality, suboptimal health care and the threat of coronavirus pandemic to global growth-we explore developments evidenced to promote economic growth.
\end{abstract}

Keywords: growth; education and health; inequality; happiness; coronavirus; Israel.

JEL codes: E00, F00, H00, I00, O4.

\section{Introduction}

The Israeli economy, its challenges, growth and setbacks, can serve as a role model addressing ancient, yet unresolved questions without satisfying answers. Why are some countries "rich" and others "poor"? What are the causes of improved living standards? What are the processes leading to economic growth? What factors cause upswings in economic activities? How do policy makers mitigate increases in price levels? What are the causes of unemploy-

${ }^{1}$ Article received 20 March 2020, accepted 8 June 2020.

The Authors extend thanks to Research Assistants Ken Johnson and Hy Pham of the City College of the City University of New York, the M.A. Economics Program, for their constructive recommendations and generous gift of time in the review and preparation of this paper.

${ }^{2}$ Department of Economics and Business, The City College and the Graduate Economic Program of the City University of New York, New York, NY 10031, USA, and The Faculty of Economic Sciences and Management, Nicolaus Copernicus University in Toruń, 13A Gagarina Str., 87-100 Toruń, Poland, yoshachmurove@gmail.com, ORCID: https://orcid.org/0000-00020236-6474.

${ }^{3}$ School of Banking and Capital Markets, Netanya Academic College, Netanya 4223587, Israel, and Department of Economics, Bar-Ilan University, Ramat-Gan, 5290002, Israel, benzionz@gmail.com, ORCID: https://orcid.org/0000-0002-5177-6568. 
ment and its fluctuations? What are the options facing policy makers for promoting economic growth, avoiding recessions, maintaining low inflation and unemployment?

This paper diagnoses the current state of the Israeli economy and indicates areas which could contribute to further improvements in its economic growth path in the new millennium. The paper describes the macroeconomic performance of the Israeli economy in the 21st millennium. It explores the development of the key macroeconomic indicators, namely growth, inflation and unemployment, over the 2000-2019 period. $^{4}$

The organization of the paper is as follows. Section 1 provides a brief literature review. Section 2 describes some key facts about the long-run economic growth of Israel. Section 3 addresses inflation. Section 4 describes the Israeli labor market. Section 5 deals with income inequality. Section 6 describes the Israeli education system and Section 7 the Israeli health system. Section 8 uses the World Happiness Report to report on the Israeli Happiness status. Section 9 offers a postscript describing how the coronavirus has affected the Israeli economy. The last part of this paper provides a brief conclusion.

\section{Literature review}

The New Growth theory has advanced significantly since the 1980s. This theory explores growth using increasing returns to scale, emphasizes the significant role of human capital accumulation and highlights the importance of endogenous technological progress (see Romer, 1986, 1990; Lucas, 1988). Galor (2011) and Galor and Weil $(1999,2000)$ present a unified growth theory from the era of Malthusian (1798) stagnation to modern growth. Acemoglu (2009), Acemoglu, Johnson and Robinson $(2001,2005)$ and Acemoglu and Robinson (2012) emphasize the crucial role of adequate institutions in promoting the accumulation of both physical and human capital, see also Barro and Sala-i-Martin (2004), Shachmurove (2007) and Jones (2016). They, among others, accentuate the significance of research and development in achieving higher growth. Lindert (2004) emphasizes the role of the state in fostering capital improvements, especially education. Mazzucato (2013) sees the government behaving as entrepreneurs supporting basic research and applied Research and Development $(\mathrm{R} \& \mathrm{D})$ as well as, taking risks, creating and shaping markets.

In an interesting paper Joffe (2017) advocates analyzing growth by employing a complex systems analysis. He claims that the economy is driven by interacting economic forces rather than responding to external non-economic influences such as preferences and technology. In this context treating economic structure as a complex system, see Holt, Rosser and Colander (2010),

\footnotetext{
${ }^{4}$ For a discussion of the Israeli economy in the first half of the 1990s, see Zilberfarb (1996).
} 
Shachmurove and Shinnar (2012), Bau and Shachmurove (2009), as well as Witkowska and Shachmurove (1997) and Shachmurove and Witkowska (2001). This idea is also employed in the seminal work by Krugman (1991) incorporating internal economies to scale and economic geography. Based on certain historical events, Shiller (2019) sees the importance of widespread stories and anecdotes that propel major economic events that have led to war, mass unemployment, and increased inequality. He claims that stories people tell increase economic confidence or raise panic, create either housing booms or busts. Such anecdotes generate economic value purely by spreading of stories. In this context advancing success stories can lead to happiness which in turn leads to a higher growth rate.

The importance of the initial condition as used in chaos theory (Bau and Shachmurove, 2009), is similar to the work by Schelling (1978), who demonstrates that a mild preference for living near people similar to oneself can eventually generate a racially segregated city. Shiller uses such a system to explain bubbles (Shiller, 2005). In the Israeli context the initial conditions of having well-organized democratic institutions before the founding of the state enabled a relatively smooth transition to democracy.

In a world-renowned book Gordon (2016) claims that, in the century after the American Civil War of 1861-1865, an economic revolution improved the American standard of living in ways previously unimaginable. The book cites examples such as electric lighting, indoor plumbing, motor vehicles, air travel and television which transformed households and workplaces. Gordon (2016) challenges the view that economic growth will continue unabated. He contends that American productivity growth will be held back by the headwinds of rising inequality, stagnating education, an aging population, the rising debt of college students and the increased debt of federal and state governments. In this way Gordon (2016) points to the importance of investing in education and in reducing inequality.

Many papers have been published over the years analyzing the Israeli economic-growth process. One of the first works in this area is Patinkin (1959) who examined the Israeli economy during its first decade. Main events which have impacted the Israeli economy have been examined by various researchers (Halevi \& Klinov-Malul, 1968; Michaely, 1975; Ben-Porath, 1986; Syrquin, 1986; Bruno, 1993; Leiderman, 1999; Ben-Bassat, 2002; Razin, 2018; Shachmurove, 2019). Lecker and Shachmurove (2001) discuss the contribution of the Israeli labor-managed Kibbutzim in narrowing the socioeconomic gap in Israel as the country moved away from socialist to a more capitalist economy.

Israel and the European Economic Community established diplomatic relations as early as 1959. The first free trade area agreement was signed in 1975. Shachmurove (1987) analyzes the effects of the integration of the Israeli economy into the European Economic Community. This agreement opens the door for Israeli exports, increases competitiveness and motivates the Israeli economy 
to build global networks, initially in Europe, consequently in the USA and currently including the emerging economies of Brazil, China, India and Russia.

The impact of the 1967 Six-Day War on the Israeli economy was researched by Zilberfarb (2018). The lasting (negative) economic effects of the 1973 Yom-Kippur War which have led to what has been called "the lost decade," is analyzed in a series of papers in Ben-Porath (1986). The failure of the foreign-exchangemarket reform in 1977 is the subject of yet another study (Zilberfarb, 1991). Birati and Shachmurove (1991) analyze the process of adjustment between price and exchange rates for the years 1977-1986. Rosenberg and Shachmurove (1987) study nominal and real shocks to the Israeli Economy, comparing the seventies versus the eighties of the last century.

In 1985 the Israeli government adopted a stabilization plan which cut inflation from $445 \%$ per annum to just $20 \%$ in a short period of time. This highly successful anti-inflation program has been the subject of many studies (see e.g. Bruno, 1993). Its fiscal institutions and their impact on budget deficits have been analysed by Zilberfarb (2005a). Birati and Shachmurove (1993) study the linkage among stock markets in selected western countries and Israel before and during the Gulf War of 1990-1991. The resumption of growth following the stabilization policy stemmed from two sources, namely the big wave of immigration from the former Soviet Union at the beginning of the 1990s and the signing of the Oslo agreement between Israel and the Palestinian Authority in 1992. The effect of these developments on the Israeli economy is analyzed in Zilberfarb $(1994,1996)$. Finally the longer view of how the Israeli economy has moved from socialism to a free market is described in Zilberfarb (2005b).

Compared with the many studies that examine the Israeli growth process in the last millennium there are only a few studies that examine the developments in the Israeli economy in the last twenty years. This paper aims to fill in this gap.

\section{Growth}

At the turn of the new millennium the initial conditions for the Israeli economy were favorable. Two chronic problems had plagued the Israeli economy for many years: a deficit in the balance of payments since the founding of the state in 1948 and inflation that had been a major problem since the end of the 1960 s. However, a dramatic change has occurred on these two fronts in the new millennium as described and analyzed below.

During the first twenty years of the new millennium Israel has doubled its real GDP. The average annual growth rate, measured by the percentage change in real GDP, was 3.6\% during the 2000-2019 period (see Figure 1). GDP per capita grew at an average of $1.63 \%$ per annum. The year 2000 was a record year in various, important macro parameters: GDP grew by $8.8 \%$, the highest 


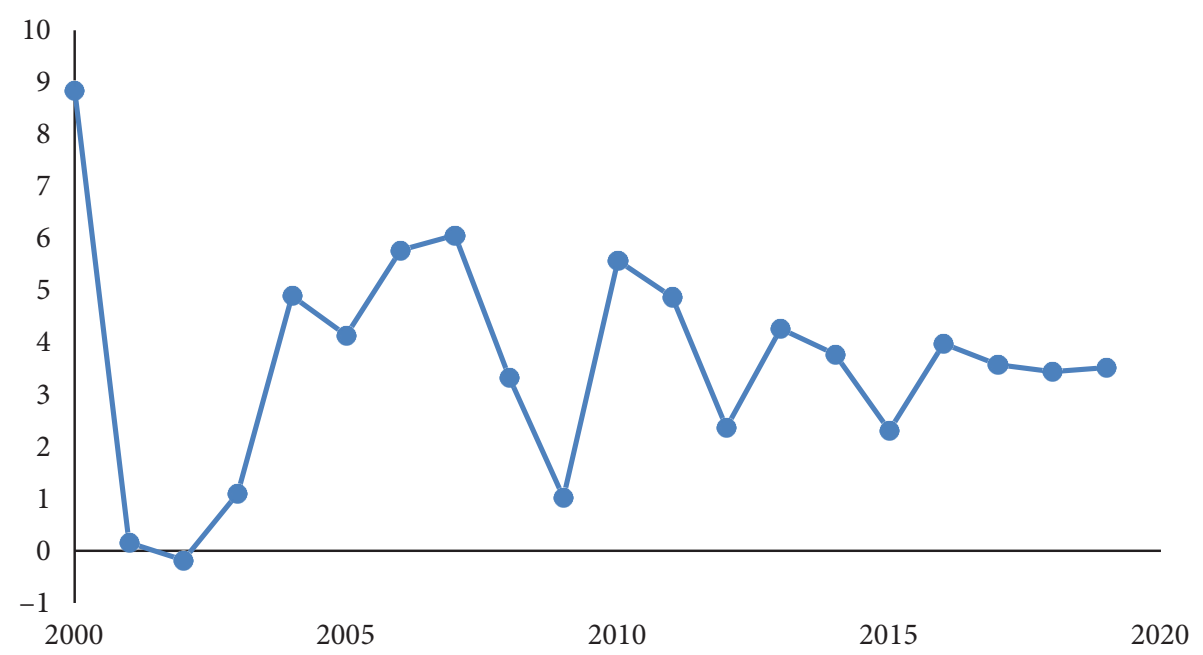

Figure 1. Percent change in Israeli Gross Domestic Product

Source: Israel Bureau of Statistics.

growth rate since the beginning of the 1970s. The inflation in that year was 0 , the lowest since 1951.

The main reason behind this remarkable growth was the high-tech boom. The National Association of Securities Dealers Automated Quotations (NASDAQ) composite index reached a record high of 5,132.5 on March 10, 2000. However, this boom ended at the year-end of 2000 with most of the internet companies' stock dropping by $75 \%$. The 9/11 terrorist attack of 2001 accelerated the stock market drop. The United States stock exchanges were closed for a week after the attack. When trading resumed on September 17, 2001, the NASDAQ fell $6.8 \%$ on the day. The NASDAQ composite index continued to fall, reaching the level of 1,180 a year later with a $75 \%$ drop!

Investments in Israeli start-up companies were very much dependent on developments in the NASDAQ market. Hence the crisis in the United States stock market led to a similar crisis in the Israeli high-tech industry which, in turn, had a major impact on the Israeli economy. The driving force for growth in Israel came to an abrupt halt leading to stagnation for the next three years. ${ }^{5}$

In addition there were other negative factors that slowed the Israeli economy. The most important of these was the outbreak of the Intifada, i.e., terrorist attacks by the Palestinians, that had started at the end of 2000. Zilberfarb (2003) argues that while the high-tech crisis was the main reason for the slowdown in 2001 the Intifada was the main cause for continuation of the recession in

\footnotetext{
${ }^{5}$ GDP grew by $0.2 \%$ in 2001 . GDP then declined by $0.2 \%$ in 2002 which was the second decline in GDP since the establishment of the State of Israel. The previous and only decline recorded before was in the year 1953. GDP resumed its growth by $1.1 \%$ in 2003.
} 
2002. Additionally erroneous monetary policy adopted by the Bank of Israel at the end of 2001 led to unrest in the financial markets and caused a jump in the inflation rate. These negative developments led the Bank of Israel to raise interest rates substantially, thereby negatively affecting growth. These developments will be described in more detail later in the inflation section.

Since 2004 the Israeli economy has resumed its growth path with GDP growing on average by $4.85 \%$ annually for the next five years (2004-2008). The year 2009 was again a year of economic slowdown. The reason for that temporary setback was the worldwide financial crisis. On September 15, 2008, Lehman Brothers Holdings, Inc. with its investment bank, the fourth largest in the USA, filed for Chapter 11 bankruptcy protection following the exodus of most of its clients and drastic losses in its stock price. After Lehman Brothers filed for bankruptcy global markets immediately plummeted.

The financial crisis that followed had an adverse effect on economies worldwide. In the year 2009, GDP fell by $2.5 \%$ in the USA, $5.7 \%$ in Germany and $4.2 \%$ in the United Kingdom (UK), to name a few. The Israeli economy was a notable exception: the worldwide recession had a negative impact on its economy, yet GDP in Israel grew by $1.1 \%$. This was a significant decrease in its growth rate compared with the previous five years but, unlike many countries, it was still a positive increase. The resilience of the Israeli economy was evident in the following years. Growth resumed to its previous pace, measuring $5.6 \%$ and $4.9 \%$ in 2010 and 2011, respectively, at a time when many developed economies were still in recessions.

A testament to the progress of the Israeli economy is the May 2010 invitation extended to Israel by the Organization for Economic Cooperation and Development (OECD) to become a member. This was the culmination of a process that started three years earlier with a resolution adopted by the OECD Council at the Ministerial level to open discussions with Israel for its membership in the Organization. The invitation resulted from the OECD Council's positive assessment of the Israeli position with respect to OECD instruments, standards and benchmarks. In the second decade of the new millennium 20102019 the Israel economy grew, on average, by $3.8 \%$ a year, inflation averaged a mere $1 \%$, and the unemployment rate declined from $6.6 \%$ to just $3.8 \%$ in 2019 .

Israel's foreign exchange reserves have increased more than fivefold in the new millennium, from $\$ 22.1$ billion in January 2000 to $\$ 122.4$ billion at the end of 2019. This was mainly a result of a shift in the Bank of Israel policy. During the second half of the 1990s the Bank of Israel adopted a policy of non-intervention in the foreign exchange market concurrent with a policy of high interest rates aimed at combating inflation. The result was an inflow of foreign exchange seeking to enjoy the high interest rates. In addition the high-tech industry attracted ample foreign direct investments.

As a result of the foreign exchange inflow the Israeli currency appreciated causing Israeli exports to become less price competitive. Industry leaders as 
well as the Ministry of Finance pressured the Bank of Israel to intervene in the market and purchase foreign currency to stop the appreciation of the domestic currency, the New Israeli Shekel (NIS). This resulted in the accumulation of foreign reserves by the Bank of Israel. An additional factor contributing to the increase in foreign reserves was the discovery of gas reserves in the Mediterranean Sea within the economic territorial waters of Israel. The Bank of Israel declared on May 2013 that it will buy foreign currency in the amount necessary to sterilize the effect of the gas revenues on the balance of payments. This policy was implemented to avoid the "Dutch disease" which affected the Netherlands after the discovery of its large Groningen natural gas field in 1959 (Corden, 1984).

\section{Inflation}

In the first half of the 1980s the Israeli economy had experienced a period of very high inflation rates, reaching a record of $444.9 \%$ inflation in 1984 . On the verge of economic collapse the government adopted a new stabilization policy in June, 1985.

The new policy was highly successful in bringing inflation down to $19.7 \%$ in 1986 and it subsequently fluctuated between $8.1 \%$ and $20.7 \%$ over the next decade. ${ }^{6}$ During the second half of the 1990s the Bank of Israel acted to bring inflation to an acceptable international level. ${ }^{7}$ Monetary policy had concentrated solely on that target in contradiction to its charter. The 1954 Bank of Israel Law specified a few targets for monetary policy. ${ }^{8}$ These targets were all ignored for the sole purpose of curbing inflation. By adopting a very restrictive monetary policy of high interest rates to combat inflation, the Bank of Israel succeeded in dramatically reducing inflation from $10.6 \%$ in 1996 to 0 in the year 2000. The succsess of bringing inflation down has led the government to adopt a policy of multi-period inflation targets rather than a one-year ahead target. In addition the government adopted the new Bank of Israel Law which put price stability as the Bank's main responsibility. ${ }^{9}$

As a result of the actions of the Bank of Israel inflation was basically eliminated as a problem. The average inflation in the 21 st century was just $1.2 \%$ per annum, fluctuating between $3.9 \%$ and minus $1.9 \%$ annually (see Figure 2). ${ }^{10}$ The year 2002 was an exception with an inflation rate of $6.5 \%$ compared with

\footnotetext{
${ }^{6}$ For more on the stabilization policy see Bruno (1993).

7 The shift in the Bank policy have actually started in 1992 with the adoption of an inflation target for 1992.

${ }^{8}$ See http://knesset.gov.il/review/data/eng/law/kns2_bank_eng.pdf

${ }^{9}$ The new Bank of Israel Law was adopted by the Israeli Parliament on May 2010.

${ }^{10}$ One exception is the year 2002 in which inflation was an unusual $6.5 \%$. This year was excluded from the calculations. The average inflation rate, including the figure for 2002 , is $1.5 \%$.
} 


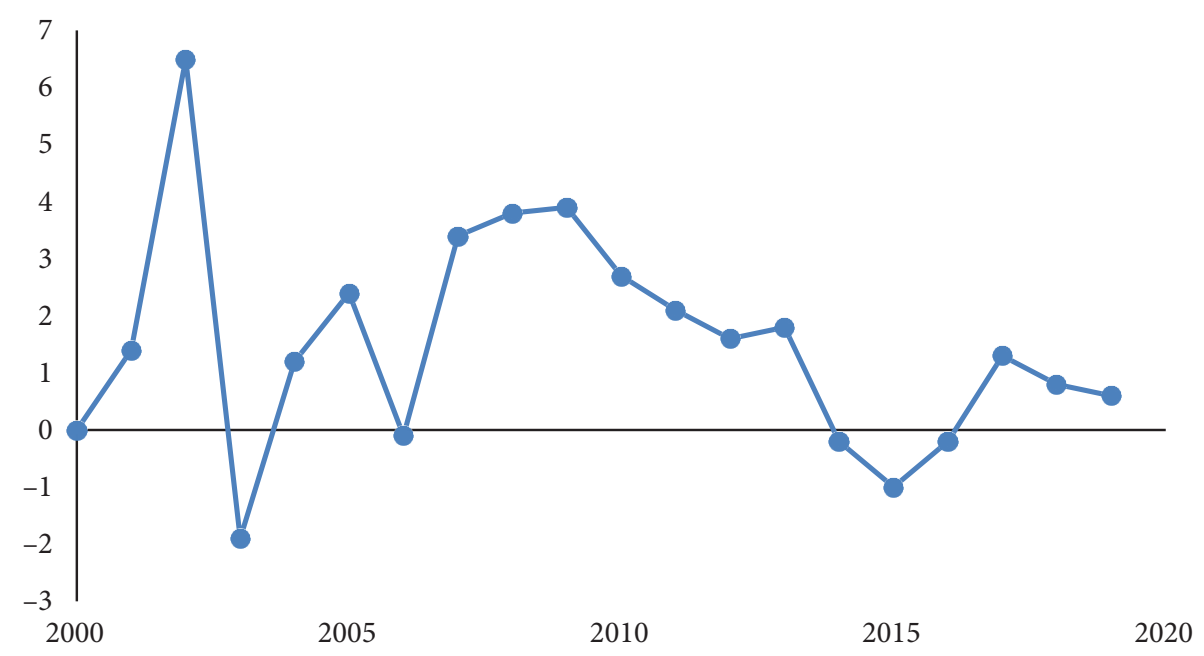

Figure 2. Inflation rate in Israel

Source: Israel Bureau of Statistics.

$1.4 \%$ in 2001 and minus $1.9 \%$ in 2003 . The reason for this one-time jump in inflation was an erroneous monetary policy. At the end of 2000, with a zero inflation rate, the Bank of Israel interest rate was $10.7 \%$ ! It was clear that this restrictive monetary policy, with a double-digit real interst rate, should change course and interest rates should go down. Indeed the Bank of Israel pursued a policy of gradually reducing the interest rate by $0.2-0.3 \%$ per month such that by the end of 2001 the interest rate was at $5.7 \%$.

In a sharp departure from its previous policy of gradual reduction of interest rates on January of 2002 the Bank of Israel reduced its interest rate by almost $2 \%$, from $5.7 \%$ to just $3.8 \%$. This rapid change triggered a devaluation of the NIS. From a rate of 4.28 NIS to the dollar the rate increased by $6.1 \%$ to 4.54 NIS per US dollar in January 2002 and reached a peak on June of that year with a rate of 4.94 , which implies a devaluation of $15.4 \%$.

The unavoidable consequence of the significant devaluation was an increase in inflation. To avoid the outbreak of inflation again the Bank of Israel reversed its course and in July, 2002 raised the interest rate to 9.1\%!, erasing all the gradual reductions of the previous two years. The Bank of Israels' interest rate, which stood at $3.8 \%$ at the beginning of 2002 , increased by more than five hundred percentage points in half of a year. It would take two more years to bring interest rates to where they were at the beginning of $2002 .{ }^{11}$ The deficit in the balance of payments continued to shrink and in 2003, for the first time in its economic history, a surplus in the balance of payments was recorded and has continued ever since.

\footnotetext{
${ }^{11}$ For an interesting discussion of the Bank of Israel anti inflation policy see Offenbacher and Elkayam (2020).
} 


\section{The labor market}

For many years one of the problematic characteristics of the Israeli economy had been the low labor force participation rates. This was mainly due to two sectors in the economy: The Arab sector, where participation rates for women were low-and the Haredim (ultra-orthodox) sector, with low participation rates for men. The low participation rates for these sectors are mainly due to culture and generous allowances for children. Culture has left many Arab women at home and many Haredim men studying all day in Yeshivot (places of religious studies) with the women providing for the family. This culture also called for large families which resulted in significant income from the generous child allowances.

In 2004 Benjamin Netanyahu, serving as the Finance Minister under Prime Minister Ariel Sharon drastically cut child allowances. The purpose of this cut was, first, to cut government expenditures to bring down the budget deficit ${ }^{12}$ and secondly, to induce people to join the labor force rather than relying on support from the government. Thus child allowance for a family of five (5), which amounted to 1,459 NIS in January of 2004, was cut to just 720 NIS in January of 2009 (a 51\% cut!). For families with eight (8) children, the cut was even more drastic: from 3,025 NIS to 1,152 NIS (a 62\% cut!). Indeed the labor force participation rate for ages $25-64$ increased from $60.3 \%$ in 2004 to $63.9 \%$ at the end of 2018 .

While the general employment rate increased in the period 2009-2018 from $70.7 \%$ to $78.2 \%$, in the Haredim sector the increase was even more impressive: from $49.3 \%$ to $61.2 \%$. In the Haredim sector the increase was even more pro-

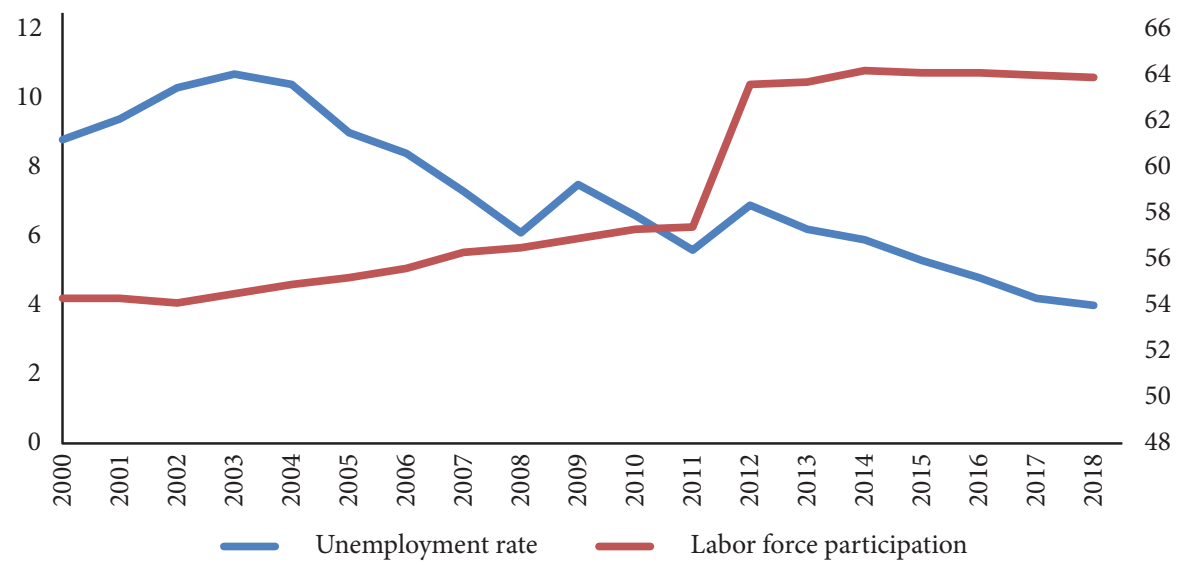

Figure 3. Labor participation and unemployment rates for 2000-2018 Source: Israel Bureau of Statistics.

${ }^{12}$ Recall that 2001-2003 were years of stagnation. 
nounced for the female employment ratio, increasing from 59.1\% in 2009 to $75.5 \%$ in 2018 and surpassing the employment rate for all women given that the corresponding figures for total female participation are $65.1 \%$ and $74.2 \%$, respectively.

In terms of the labor market the achievements of the Israeli economy are remarkable. Figure 3 depicts labor participation and unemployment rates for the 2000-2018 period. The scissors movement illustrates this achievement: while labor force participation rates increased through the 2000-2018 period from $54.3 \%$ to $63.9 \%$ in 2018 the unemployment rate decreased dramatically at the same time from $8.8 \%$ to just $4.0 \%$ in 2018. Since March of 2019 the unemployment rate has stayed below $4 \%$ for the first time since the late 1970 s. $^{13}$

\section{Inequality}

Following the literature review above (e.g. Gordon, 2016) the growing trend of rising inequality has been a source of concern to the Israeli society. At the beginning of the new millennium the Gini coefficient which is the most widely used measure of inequality, was $0.350 .{ }^{14}$ It had continuously risen until reaching a record high of 0.392 in 2006 . The increase in inequality in those years may be attributed, inter alia, to measures taken by the government to reduce its budget deficit and increase the incentives to join the labor force. As discussed above this policy initiated by the Minister of Finance (Benjamin Netanyahu), included a deep cut in child allowances. This affected large families which are prevalent in the Arab and the Haredim sectors of society.

As discussed in the preceding section these sectors had a low level of labor force participation rates which have been attributed to, among other factors, the generous child allowances. It is no wonder that the cut in those allowances led to greater inequality in the short run. However in the longer run it has caused those families to join the labor force, a source for the increase in labor force participation rates (see Figure 4). This, in turn, helped to reduce inequality. The Gini coefficient has exhibited a declining pattern from 2007 onward. In 2017 it stood at a low of 0.352 .

In addition other measures to increase the incentive to join the labor force were adopted over the years and have contributed to the decline in inequality. The minimum wage that was NIS 3,585 in 2006 (about \$800 US) increased in seven steps from 2011 until 2017 almost doubling in dollar terms. The last step in December 2017 fixed it at NIS 5,300 (\$1,520 US). Another measure was the

\footnotetext{
${ }^{13}$ The figure for the unemployment rate for 2019 was $3.8 \%$.

${ }^{14}$ A higher coefficient implies a greater level of inequality. Zero coefficient means complete equality while one implies complete inequality.
} 


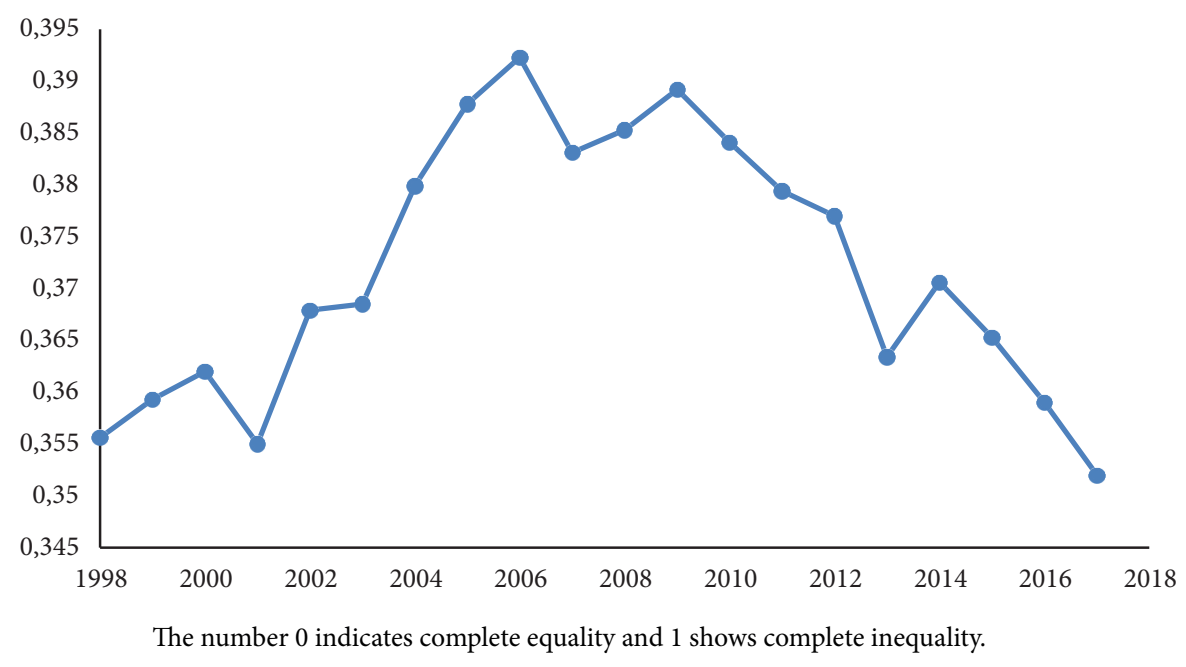

Figure 4. The Gini coefficient (after income tax and allowances)

Source: Annual Reports National Insurance Institute of Israel, various issues.

institution of a negative income tax in 2008. This has been paid to low income workers providing an incentive to go to work.

The above measures, coupled with the resumption of growth from 2004 onward, all have contributed to the downwards trend in inequality since 2007. However it should be emphasized that inequality in Israel remains relatively high. Recent data from the OECD place Israel in the 28th place, out of 40 countries, in terms of the Gini coefficient.

\section{The Israeli education system}

As mentioned above the New Growth theory explores growth using increasing returns to scale emphasizes the significant role of human capital accumulation and highlights the importance of endogenous technological progress. Indicators of education system quality are useful measures of the strength of an economy. The Israeli education system is another main engine of Israel's continuous economic growth. The educational apparatus in Israel is aimed at promoting innovations, entrepreneurship and "outside-the-box" thinking.

Table 1 presents some indicators for primary and high school education. For primary education the percentage of teachers with at least one graduate degree in primary education has increased 2.9 fold, from $9.4 \%$ in the year 2000 to $27.2 \%$ in 2018 . The average number of students per class, excluding special education classes, decreased from 27.0 in 2000 to 24.7 in 2018. The average grade for all fifth grade students, standardized in order to allow for comparison between years, shows improvement between the first year the examina- 


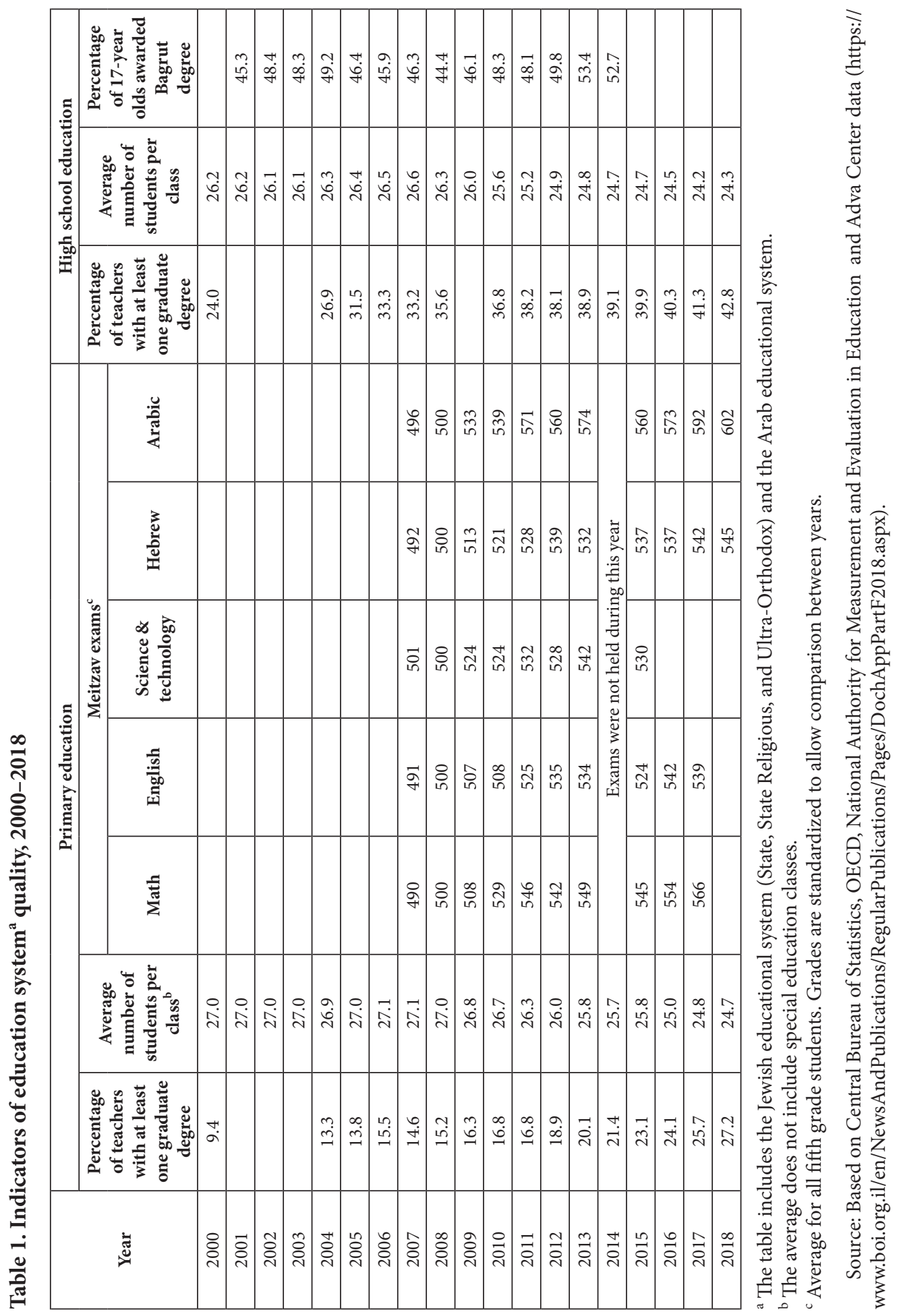


tions were given in 2007 compared to 2018. The examinations cover the areas of Math, English, Science and Technology, Hebrew and Arabic.

For high-school education the percentage of teachers with at least one graduate degree in primary education has increased from $24.0 \%$ in the year 2000 to $42.8 \%$ in 2018 . The average number of students per high school class decreased from 26.2 in 2000 to 24.3 in 2018. The percentage of 17-year olds awarded Bagrut, which is a matriculation examination, has increased from $45.3 \%$ in 2001 to $52.7 \%$ in 2018 .

Table 2 presents the data for the number of ultra-orthodox Jews and Arab Israelis as well as their percentage of the Israeli population for the years 2009 , 2014 and 2017. Both populations are increasing in number and as a percentage of the population. This increase presents a challenge to the Israeli economy due to the lack of adequate mathematics and core science education, especially for the male populations. For a critical long-run analysis of the math education for the majority of ultra-Orthodox children, see Ben-David (2019). He claims that the poor level of math education for this group, primarily the boys beyond the eighth grade, presents existential challenges for Israel's future.

Table 2. Ultra-Orthodox Jews as percentage of population (thousands)

\begin{tabular}{|l|c|c|c|c|c|c|}
\cline { 2 - 7 } \multicolumn{1}{c|}{} & \multicolumn{2}{c|}{2009} & \multicolumn{2}{c|}{2014} & \multicolumn{2}{c|}{2017} \\
\cline { 2 - 7 } \multicolumn{1}{c|}{} & Number & \% of Total & Number & \% of Total & Number & \% of Total \\
\hline $\begin{array}{l}\text { Ultra- } \\
\text { Orthodox }\end{array}$ & 750 & 10 & 911 & 11 & 1,033 & 12 \\
\hline Other Jews & 5,267 & 70 & 5,560 & 68 & 5,921 & 67 \\
\hline $\begin{array}{l}\text { Arab } \\
\text { Israelis }\end{array}$ & 1,536 & 20 & 1,713 & 21 & 1,835 & 21 \\
\hline Total & 7,553 & & 8,184 & & 8,789 & \\
\hline
\end{tabular}

Source: Israel Democracy Institute (https://www.jewishvirtuallibrary.org/latest-populationstatistics-for-israel).

\section{The Israeli health system}

Although the Israeli health system needs major improvements the system benefits from its ability to adapt extremely well to emergencies utilizing its own resources as well as sophisticated army branches of health and innovative agencies that are deployed at times of emergency. Examples of this include the rapid adaptation of the Israeli health system to recurring missile attacks on the Israeli civilian population and its response to the recent coronavirus pandemic.

Table 3 compares a few indicators of health system quality for the years 2000 until 2017 between Israel and the average of all OECD countries. Throughout 


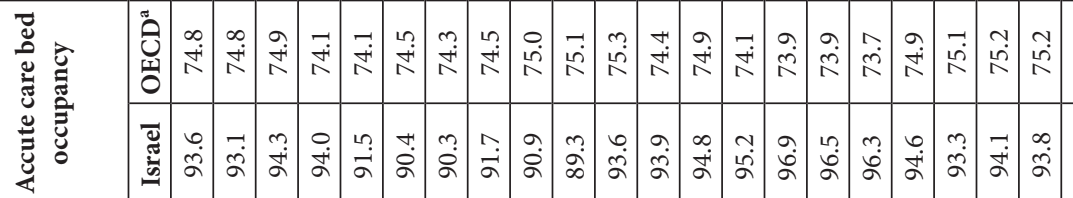

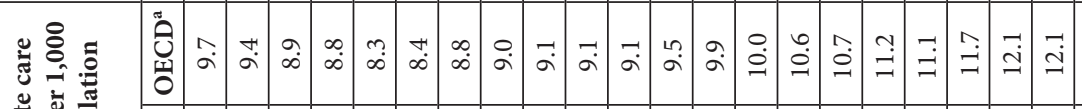

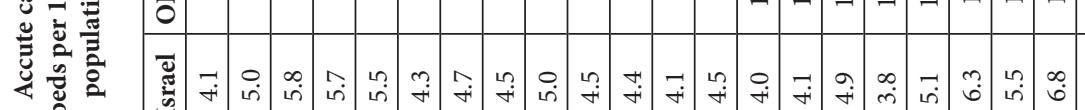

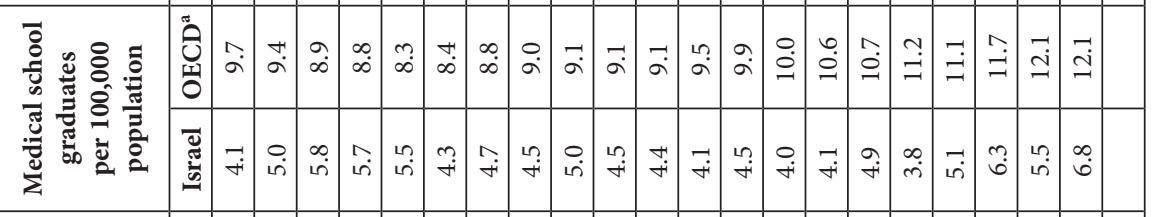

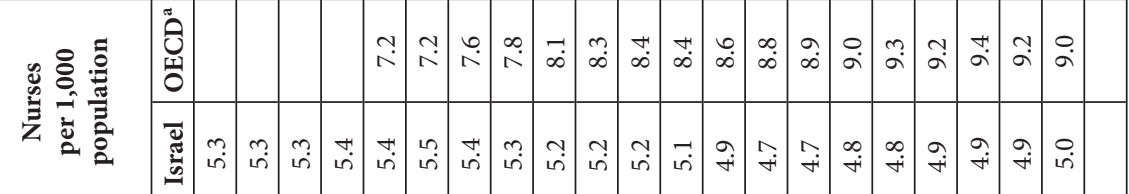

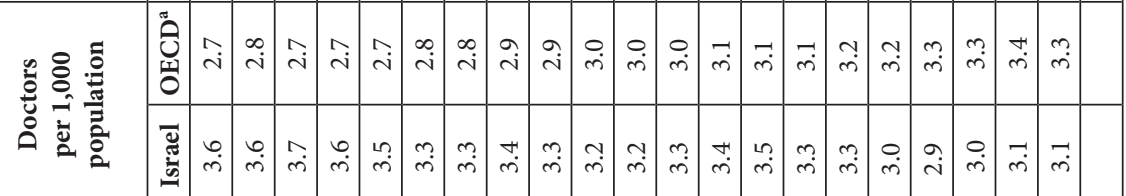

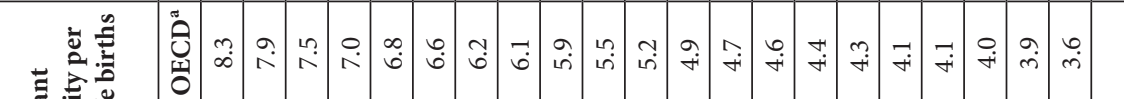

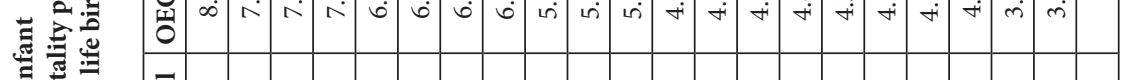

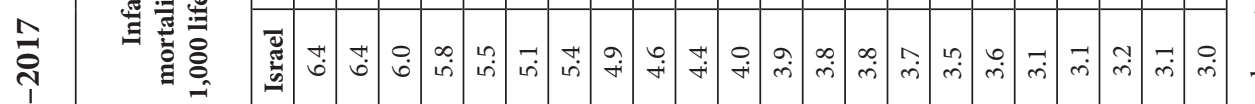

ఏे

ב

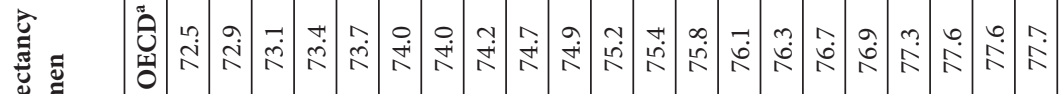

:

焉 $\stackrel{\leftrightarrow}{\dddot{2}}$

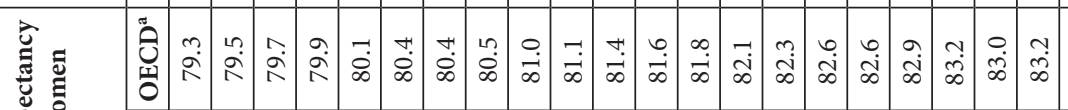

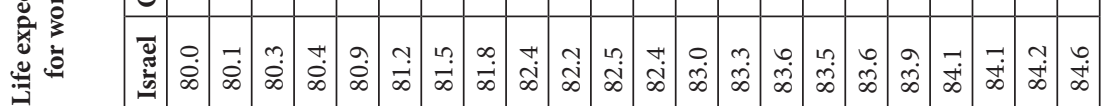

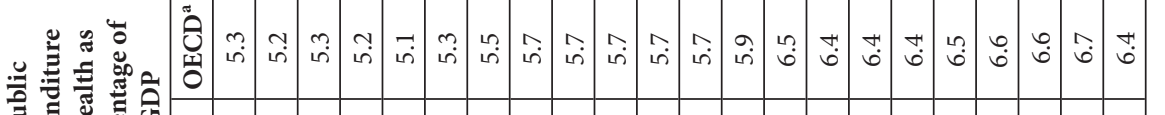

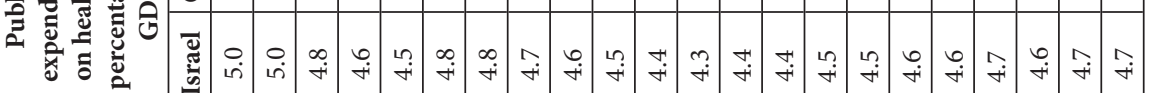

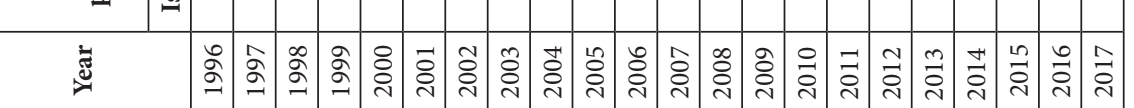

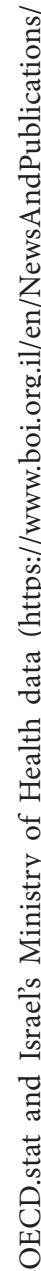

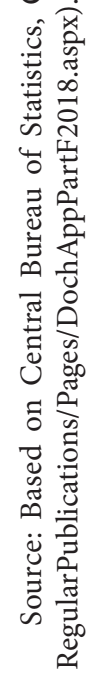


these years, despite lower public expenditures on health as percentage of GDP in Israel, some measures of health quality are higher. For example in the year 2000 public expenditures on health were 4.6 percent of GDP, the corresponding average for the OECD countries was 5.1 percent. In 2017 the figures are 4.7\% versus $6.4 \%$. Yet life expectancy for both women and men are higher in Israel ( 80.9 versus 80.1 in 2000 and 84.2 versus 83.2 in 2016, the last year for which data are available). Infant mortality per 1,000 births has been lower in Israel (5.5 versus 6.8 in 2000 and in 20163.1 versus 3.6 for Israel versus the OECD, respectively). In terms of the number of doctors per 1,000 of the population Israel had more doctors than the OECD through the years 2000 until 2011. This trend has reversed in the years 2012 until 2017.

Other indicators of health system quality are not on par when compared with the OECD countries. With respect to nurses per 1,000 of the population, Israel has consistently lower numbers relative to the OECD countries (5.5 in 2000, 5.0 in 2016, versus 7.2 in 2000 and in 20169.0 in the OECD). In terms of medical school graduates per 100,000 of the population, Israel had 5.5 versus 8.3 in 2000 and in 20166.8 versus 12.1 for the OECD. In terms of acute care beds per 1,000 of the population, Israel lags behind (5.5 versus 8.3 in 2000 and in 20166.8 versus 12.1 relative to the OECD). The acute care beds' data are also reflected in the measure of acute care bed occupancy, which show an unfavorable difference for Israel of $91.5 \%$ versus $74.1 \%$ for the year 2000 and 93.8\% versus $75.2 \%$ in 2016 for the average of OECD countries. Clearly the Israeli government has to allocate more resources to the health sector consistent with endogenous economic growth theory.

Despite allocating less than adequate resources for the health sector the ranking of the world's best hospitals ${ }^{15}$ in the year 2019 includes one of the Israeli hospitals which is ranked among the ten best hospitals in the world. Of the top ten hospitals, USA has four of the ten best hospitals with the other hospitals located in Singapore, Germany, Canada Japan and Switzerland. In the same survey for the year $2020^{16}$ the same Israeli hospital is ranked in 9th place and another hospital is ranked at the respected 34th place.

\section{The World Happiness Report}

One of the elements necessary, indeed essential, to the factors causing upswings in economic activities are measures of happiness. Keynes (1936) writes about the animal spirits, the instincts, proclivities and emotions that ostensibly influence and guide human behavior. Although GDP growth does not necessarily lead to happiness it seems inherent that happinesss and optimistic spirits in-

\footnotetext{
${ }^{15}$ https://www.newsweek.com/2019/04/05/10-best-hospitals-world-1368512.html

${ }^{16}$ https://www.newsweek.com/best-hospitals-2020
} 
crease labor productivity (see i.e. Shiller, 2019; DiTella, MacCulloch, \& Oswald, 2001; van Praag, Romanov, \& Ferrer-i-Carbonell, 2010). ${ }^{17}$

An indicator of this state in the Israeli economy is the 2019 United Nations World Happiness Report (WHR). ${ }^{18}$ The WHR is a survey of global happiness that ranks 156 countries by how happy their citizens perceive themselves to be. The 2019 report focuses on happiness and community, i.e. how happiness has evolved over the past dozen years with a focus on the technologies, social norms, conflicts and government policies that have driven those changes.

According to the WHR Israel ranks 13th among the 156 countries surveyed. By comparison, the USA ranks 19th and Poland ranks 40th (Helliwell, Layard, \& Sachs, 2019; Helliwell, Layard, Sachs, \& De Neve, 2020). In the category of healthy life expectancy, Israel ranks 11th (USA-31, Poland-36). Despite these encouraging rankings, there is a lot to improve upon. In the category of social support, Israel ranks 38th (USA-37, Poland-44), in Freedom 93th (USA-62, Poland-52), in corruption 73th (USA-42, Poland, a very law rank of-108), and, even in generosity, Israel ranks only 24 th (USA-10, Poland-41).

According to the same WHR document the percentage of respondents within the country who reported donating money to a charity in the past month is $51.9 \%$ (USA, $62.3 \%$, Poland, $28.9 \%$ ). The percentage of respondents within the country who reported volunteering time to an organization in the past month is $23.1 \%$ (USA, $42.4 \%$, Poland, $1.5 \%$ ).

\section{Postscript: 2020 and beyond-a note on the coronavirus (COVID-19)}

At the time of writing the coronavirus is an ongoing pandemic which first brokeout in Wuhan, Hubei province, China in December 2019. The World Health Organization (WHO) declared a Public Health Emergency of International Concern on 30 January 2020 and recognized it as a pandemic on 11 March 2020.

As of April 20, 2020 about 5 million cases of COVID-19 have been reported in over 200 countries and territories, resulting in approximately 326,464 deaths to date (see, https://coronavirus.jhu.edu/map.html). The USA has confirmed over 1.5 million cases with over 93,000 deaths to date. Poland has 19,700 confirmed cases with 962 deaths to date. Israel has 16,600 confirmed cases, with 279 deaths. Thus it seems that the Israeli government and its health authorities have been able to put a grip on this pandemic.

As is evident from the above analysis at the turn of the third decade of the millennium, Israel was set to continue its growth pattern. However, two devel-

\footnotetext{
${ }^{17}$ See, the objection by Oishi and Kesebir (2015).

${ }^{18}$ https://worldhappiness.report/ed/2019/
} 
opments, one internal and one external, have threatened this path. The internal obstacle to growth is the political stalemate over the last two years. After calling for elections in April 2019 the Likud party that has been in power since 2009 was unable to form a coalition and second election were called in September 2019. This second election resulted again in a stalemate forcing a third round of elections in December 2019.

Three rounds of elections in such a short period of time have never happened in Israel. The lack of an elected government did not enable passage of a new budget for 2020. According to Israeli law the budget for 2020 was kept at its 2019 level and each month the Treasury allowed government outlays equal to $1 / 12$ of the 2019 annual budget. The paralysis of the budget process has not enabled corrective measures to reduce the budget deficit which was higher than planned for 2019 as well as shifting resources to accommodate changing priorities. ${ }^{19}$ While a new coalition was recently formed a new threat to growth arose from an external source: The Coronavirus.

In the face of this pandemic a closure has been imposed on the population that has brought the economy to a sudden halt. Schools were mandated to close and people are instructed to stay at home, either voluntarily or by government orders. Firms have sent most of their workers on forced unpaid leave and, as such, they were eligible for unemployment benefits. ${ }^{20}$ Consequently the unemployment rate that was just $4 \%$ prior to the outbreak of the coronavirus jumped to $25 \%$, the highest it has ever been in Israel. ${ }^{21}$ It is expected that, once the pandemic is over, most of these unemployed workers will return to their old jobs. Based on previous experience it is estimated that $80 \%$ of the newly, temporarily, unemployed individuals will find jobs. If this is indeed the case then the unemployment rate will likely decline to about $9 \%$, but still a big jump from the rates that have prevailed in recent years.

The consequences of the current Corona crisis are uncertain. No one at this point can predict when the pandemic will be over or, once it is over, how many businesses will go bankrupt and at what pace other firms that survived the crisis will resume their previous levels of operation. This depends, inter alia, on how people will change their expenditures pattern. Thus many issues remain uncertain. Will consumers shift more rapidly to buying online? Will they increase their level of savings, thus reducing their level of consumption?

${ }^{19}$ The actual deficit was $3.7 \%$ of GDP higher than the original target of $2.9 \%$.

${ }^{20}$ It is estimated that out of about 1 million people registered at the unemployment offices of whom about 800 thousand are workers on involuntary leaves.

${ }^{21}$ It should be noted that this rate of unemployment does not correspond to the methodology of the International Labor Organization (ILO). According to the ILO definition (which has been adopted by the Israeli Bureau of Statistics) those who are on a forced leave are considered as temporarily absent from work and not unemployed. Thus while the official unemployment rate in March was just 3.1\%, if we include those on a forced leave the figure jumps to $21 \%$. 
Will they resume their business and leisure habits such as use of restaurants, hotels, domestic flights and international travel?

According to recent forecasts released by the Bank of Israel GDP will decline by $4.5 \%$ in 2020 . The Israeli Ministry of Finance has similar figures-GDP decline of $5.5 \%$ and government deficit of $11 \%$ of GDP. The International rating agency Fitch estimates that Israel's GDP will decline by $5.6 \%$ this year and grow at 5\% next year. However, the Bank of Israel has a more optimistic forecast, with an estimated growth rate at $6.8 \%$. Corresponding figures for 2020 in the Euro zone, USA and UK are $-7 \%,-5.6 \%$ and $-6.3 \%$, respectively.

\section{Conclusions}

The performance of the Israeli economy over the last twenty years has been quite impressive. It withstood two economic storms that affected economies worldwide. The first was the dot-com crisis at the turn of the new millennium and the second was the financial crisis that followed the collapse of Lehman Brothers in the USA. In both cases the impacts on the Israeli economy were mild unlike in many other developed countries. This was due to adequate economic policy and the strength of the Israeli financial system.

In the period 2000-2019 the average annual growth rate of GDP was 3.6\% ( $1.6 \%$ in per capita terms) and the unemployment rate declined from $8.8 \%$ to just $4 \%$ concurrent with an increase in the labor participation rate from $54.3 \%$ to $63.9 \%$. The deficit in the balance of payments that had characterized the Israeli economy since the establishment of the state in 1948 had been eliminated and turned into a surplus since 2003 mainly due to the impressive increase in the exports of the high-tech sector.

However, as this paper goes to print economies worldwide, including Israel, are facing the coronavirus pandemic which is having a significant negative impact on economic activity. The economic consequences of these pandemic are left for future research.

\section{References}

Acemoglu, D. (2009). Introduction to modern economic growth. Princeton: Princeton University Press.

Acemoglu, D., Johnson, S., \& Robinson, J. A. (2001). The colonial origins of comparative development: An empirical investigation. American Economic Review, 9(5), 1369-1401.

Acemoglu, D., Johnson, S., \& Robinson, J. A. (2005). Institutions as fundamental cause of long-run growth. In Ph. Aghion, S. Durlauf (Eds.), Handbook of economic growth (pp. 385-472). Amsterdam: Elsevier. 
Acemoglu, D., \& Robinson, J. A. (2012). Why nations fail. New York: Crown.

Bau, H., \& Shachmurove, Y. (2009, January). Process unpredictability in deterministic systems. In J. V. Ciprut, (Ed.), Indeterminacy, the mapped, the navigable and the uncharted (pp. 215-240). Cambridge, MA: MIT Press.

Ben-Bassat, A. (2002). The Israeli economy, 1985-1998: From government intervention to market economics. Cambridge, MA: MIT Press.

Ben-David, D. (2019). Doing (learning) the math in Israel conflicting demographic trends and the core curriculum. Shoresh Policy Brief.

Ben-Porath, Y. (Ed.).(1986). The Israeli economy: Maturing through crises. Cambridge, MA: Harvard University Press.

Barro J. R., \& Sala-i-Martin, X. (2004). Economic growth (2nd ed.). Cambridge, MA: MIT Press.

Birati, A., \& Shachmurove, Y. (1991, April). The process of adjustment between price and exchange rates-Israel 1977-1986. Quarterly Banking Review, 29(115), 43-54.

Birati, A., \& Shachmurove, Y. (1993, March). The linkage among stock markets in selected Western countries and Israel before and during the Gulf Crisis. Quarterly Banking Review, 31(123), 82-98.

Bruno, M. (1993). Crisis, stabilization, and economic reform: Therapy by consensus. Oxford: Clarendon Press.

Corden, W. M. (1984). Boom sector and Dutch disease economics: Survey and consolidation. Oxford Economic Papers, 36(3), 359-380. doi:10.1093/oxfordjournals. oep.a041643

DiTella, R., MacCulloch, R. J., \& Oswald, A. J. (2001). Preferences over inflation and unemployment: Evidence from surveys of happiness. American Economic Review, 91(1), 335-341.

Galor, O. (2011). Unified Growth Theory. Princeton: Princeton University Press.

Galor, O., \& Weil, D. (1999). From Malthusian stagnation to modern growth. American Economic Review, 89(2), 150-154.

Galor, O., \& Weil, D. (2000). Population, technology, and growth: From Malthusian stagnation to the demographic transition and beyond. American Economic Review, 90(4), 806-828.

Gordon, R. J. (2016). The rise and fall of American growth. The US standards of living since the Civil War. Princeton: Princeton University Press.

Halevi, N., \& Klinov-Malul, R. (1968). The economic development of Israel. Praeger Special Studies in International Economics and Development, published in cooperation with the Bank of Israel. New York: Frederick A. Praeger Publishers.

Helliwell, J. F., Layard, R., \& Sachs, J. D. (2019). World Happiness Report 2019. New York: Sustainable Development Solutions Network.

Helliwell, J. F., Layard, R., Sachs, J. D., \& De Neve, J. E. (Eds.). (2020). World Happiness Report 2020. New York: Sustainable Development Solutions Network.

Holt, R. P. F., Rosser, J. B., \& Colander, D. (2010). The complexity era in economics. (Middlebury College Economics Discussion Paper No. 10-01).

Joffe, M. (2017). Evidence and the micro-foundations of economic growth. Economics and Business Review, 17(3), 52-79. DOI:10.18559/ebr.2017.3.4

Jones, C. I. (2016). The facts of economic growth. In J. B. Taylor, H. Uhlig (Eds.), Handbook of macroeconomics (pp. 3-69). Amsterdam: Elsevier. 
Keynes, J. M. (1936). The general theory of employment, interest and money. London: Macmillan.

Krugman, P. (1991). Increasing returns and economic geography. Journal of Political Economy, 99(3), 483-499.

Lecker, T., \& Shachmurove, Y. (2001). Have the Kibbutzim helped to narrow the socioeconomic gap in Israel? Jewish Population Studies 29, Papers in Jewish Demography 1997, Jerusalem.

Leiderman, L. (Ed.). (1999). Inflation and disinflation in Israel. Jerusalem: Bank of Israel.

Lindert, P. H. (2004). Growing public: Social spending and economic growth since the eighteenth century (2 vols). Cambridge, MA: Cambridge University Press.

Lucas, R. E., Jr. (1988). On the mechanics of economic development. Journal of Monetary Economics, 22(1), 3-42.

Malthus, T. R. (1798). An essay on the principle of population. London: J. Johnson.

Mazzucato, M. (2013). The entrepreneurial state: Debunking public vs. private sector myths. London: Anthem Press.

Michaely, M. (1975). Foreign trade regimes and economic development: Israel. New York: National Bureau of Economic Research, Columbia University Press.

Offenbacher, A., \& Elkayam, D., (2020, January 20). Adoption of the inflation targeting regime globally and its implementation in Israel (Bank of Israel Discussion Paper). Research Department.

Oishi, S., \& Kesebir, S. (2015). Income inequality explains why economic growth does not always translate to an increase in happiness. Psychological Science. doi:10.1177/0956797615596713

Patinkin, D. (1959). The Israel economy: The first decade. Jerusalem: Maurice Falk Project for Economic Research in Israel.

Razin, A. (2018). Israel and the world economy: The power of globalization. Cambridge, MA: MIT Press.

Romer, P. M. (1986). Increasing returns and long-run growth. Journal of Political Economy, 94(5), 1002-1037.

Romer, P. M. (1990). Endogenous technological change. Journal of Political Economy, 98(5), 71-102.

Rosenberg, Y., \& Shachmurove, Y. (1987). Nominal and real shocks to the Israeli economy-the seventies versus the eighties. Issues in Israel's Economy.

Schelling, T. (1978). Micromotives and macrobehavior. New York: Norton and Co.

Shachmurove, Y. (1987). The integration of the Israeli economy into the European Economic Community: Recent trends and a forecast. In I. Greilsammer, J. H. Weiller (Eds.), European Community and the state of Israel: Economic, political and institutional aspects (pp. 73-112). Berlin and New York: De Gruyter.

Shachmurove, Y. (2007). Innovation and trade: Introduction and comments. In E. Sheshinski, R. J. Strom, W. J. Baumol (Eds.), Entrepreneurship, innovation, and the growth mechanism of the free-enterprise economies (pp. 247-260). Princeton: Princeton University Press.

Shachmurove, Y. (2019). Determinants of economic growth in Israel. In M. Osińska (Ed.), Economic miracles in European economies (pp. 99-121). Cham: Springer International Publishing AG. 
Shachmurove, Y., Shinnar, R. (2012). An essay in favor of dynamic partial control of the economy. International Journal of Business, 17(3), 221-237.

Shachmurove, Y., \& Witkowska, D. (2001). Dynamic interrelation among major world stock market: A neural network analysis. International Journal of Business, 6(1), 1-22.

Shiller, R. J. (2005). Irrational exuberance (2nd ed.). Princeton: Princeton University Press.

Shiller, R. J. (2019). Narrative economics. How stories go viral \& drive major economic events. Princeton: Princeton University Press.

Syrquin, M. (1986). Economic growth and structural change: An international perspective. In Y. Ben-Porath (Ed.), The Israeli economy: Maturing through crises (pp. 42-74). Cambridge, MA: Harvard University Press.

van Praag, B. M. S., Romanov, D., \& Ferrer-i-Carbonell, A. (2010). Happiness and financial satisfaction in Israel: Effects of religiosity, ethnicity, and war. Journal of Economic Psychology, 31(6), 1008-1020.

Witkowska, D., \& Shachmurove, Y. (1997). Analiza rynków kapitałowych na świecie przy wykorzystaniu sztucznych sieci neuronowych. In T. Trzaskalik (Ed.), Zastosowania badań operacyjnych (pp. 333-348). Łódź: Absolwent.

Zilberfarb, B. Z. (1991). Foreign exchange market liberalization: Anatomy of a failure. In A. L. Hillman (Ed.), Markets and Politicians-Politicized Economic Choice (pp. 357-363). Boston: Kluwer.

Zilberfarb, B. Z. (1994, autumn). The effects of the peace process on the Israeli economy. Israel Affairs, 1(1), 84-95.

Zilberfarb, B. Z. (1996, autumn). The Israeli economy in the 1990s: Immigration, the peace process, and the medium-term prospects for growth. Israel Affairs, 3(1), 1-13.

Zilberfarb B. Z. (2003, fall). The Israeli economy in 2004: Continued recession or beginning of growth?. The Nation, 153, 44-49.

Zilberfarb, B. Z. (2005a). Budget deficits and the development of fiscal institutions in Israel 1986-2002. In A. Bareli, D. Gutwein, T. Freeling (Eds.), The shaping of the Israeli society (pp. 71-89). Beer Sheba: The Ben-Gurion Heritage Center, BenGurion University.

Zilberfarb, B. Z. (2005b). From socialism to free market-the Israeli economy, 1948-2003. Israel Affairs, 11(1), 12-22. doi:10.1080/1353712042000324427

Zilberfarb, B. Z. (2018, August). The short- and long-term effects of the Six Day War on the Israeli economy. Israel Affairs, 24(5), 1-14. doi:10.1080/13537121.2018.1505476 